\title{
Accounting for the Nutrients in Reclaimed Water for Landscape Irrigation ${ }^{1}$
}

\author{
Christopher J. Martinez, Mark W. Clark, Gurpal S. Toor, George J. Hochmuth, and Lawrence R. \\ Parsons $^{2}$
}

Reclaimed water contains nutrients that can be used by plants. When irrigating with reclaimed water, these nutrients can likely replace some of the fertilizer that might otherwise be applied. This substitution can result in financial savings in fertilizer costs for reclaimed water users. For many individuals who decide to irrigate with reclaimed water the question may not be, "Can I reduce my fertilizer inputs?" but rather, "How much can I reduce my fertilizer inputs?"

Taking advantage of the nutrients in reclaimed water requires understanding and practicing several important aspects that greatly influence how effectively plants use nutrients. Irrigation systems must be operated, maintained, and calibrated properly to maximize the nutrient uptake efficiency of the plants. The seasonal variation in the supply of nutrients in reclaimed water should be taken into consideration to ensure that the amount of nutrients desired is supplied at the right time and can be effectively utilized by plants. Fertilization plans should be adjusted to account for the seasonal variation in the supply of nutrients from reclaimed water.

Several important aspects of reclaimed water irrigation must be understood and practiced to avoid unintended environmental impacts. Irrigation systems must be operated, maintained, and calibrated properly to avoid over-spray onto paved surfaces, over-irrigation, and leaching of the nutrients in reclaimed water or applied fertilizer. Applying fertilizer without accounting for the nutrients supplied by reclaimed water could result in applying more nutrients than plants can use or soil can retain. This can result in runoff and leaching of excess nutrients and pollution of lakes, river, streams, and groundwater.

It is important to note that the total amount of nutrients supplied when irrigating with reclaimed water is not necessarily the amount that plants can use. Effective utilization of the nutrients in reclaimed water will depend on the timing of supply and proper irrigation practices. This publication presents basic information for those using reclaimed water to irrigate lawns and landscapes. The information can serve as a guide to determine whether there is an opportunity to replace some of the fertilizer that might otherwise be applied and to offer guidance on avoiding runoff and leaching of excess nutrients.

\section{What Nutrients Are in Reclaimed Water?}

Nitrogen $(\mathrm{N})$ and phosphorus $(\mathrm{P})$ are the two primary nutrients found in reclaimed water. Other micronutrients are also found in small amounts. However, they are usually not included in routine analyses. Most of the $\mathrm{N}$ and $\mathrm{P}$ in

1. This document is AE479, one of a series of the Agricultural and Biological Engineering Department, Florida Cooperative Extension Service, Institute of Food and Agricultural Sciences, University of Florida. Original publication date August 2011. Visit the EDIS website at http://edis.ifas.ufl.edu.

2. Christopher J. Martinez, assistant professor, Department of Agricultural and Biological Engineering; Mark W. Clark, associate professor, Soil and Water Science Department; Gurpal S. Toor, assistant professor, Soil and Water Science Department; George J. Hochmuth, professor, Soil and Water Science Department; and Lawrence R. Parsons, professor, Horticultural Sciences Department; Florida Cooperative Extension Service, Institute of Food and Agricultural Sciences, University of Florida, Gainesville, FL 32611. 
reclaimed water are found in forms that plants can easily use (e.g., Duncan et al. 2009). For more information on the plant-availability of nutrients in reclaimed water and a summary of several research studies, see Martinez and Clark (2009; http://edis.ifas.ufl.edu/ae449). For more information on crop irrigation and types of micronutrients that can be found in reclaimed water, see Parsons (2009; http://edis.ifas. ufl.edu/hs1157).

\section{How Much Nitrogen and Phosphorus Are in Reclaimed Water?}

The amounts and forms of $\mathrm{N}$ and $\mathrm{P}$ in reclaimed water vary from utility to utility and can vary by time of the year. Therefore, quantities of $\mathrm{N}$ and $\mathrm{P}$ must be known to incorporate reclaimed water into a landscape fertilization plan. In addition, changes in water chemistry can occur between the point the reclaimed water leaves the treatment plant (where measurements are routinely taken) and the point of irrigation. The local utility that provides the reclaimed water can be a source for this information.

\section{How to Calculate the Amount of Nitrogen and Phosphorus Supplied by Reclaimed Water}

Calculating the amount of $\mathrm{N}$ and $\mathrm{P}$ applied when irrigating with reclaimed water is easy to do. All that must be known is the quantity of reclaimed water used for irrigation (in either inches or gallons) and the concentration of $\mathrm{N}$ and $\mathrm{P}$ in the reclaimed water, measured in either units of milligrams per liter $(\mathrm{mg} / \mathrm{L})$ or parts per million (ppm).

It is important to note that the amount of $\mathrm{N}$ and $\mathrm{P}$ applied when irrigating with reclaimed water is not necessarily the amount that can be used by the plant. Proper irrigation is extremely important to effectively utilize the $\mathrm{N}$ and $\mathrm{P}$ in reclaimed water. Over-irrigation will reduce the proportion of $\mathrm{N}$ and $\mathrm{P}$ that can be used by the plant, no matter what concentrations are present. In addition, the timing of application of $\mathrm{N}$ and $\mathrm{P}$ in reclaimed water is important for effective utilization. The importance of proper irrigation and the timing of the supply of $\mathrm{N}$ and $\mathrm{P}$ in reclaimed water are discussed in more detail in later sections of this publication.

\section{Using Inches of Irrigation Applied}

To calculate the amount of $\mathrm{N}$ applied (in units of pounds $\mathrm{N}$ per 1000 square feet) from the number of inches of reclaimed water used for irrigation and the $\mathrm{N}$ concentration, use the following equation: $\frac{\mathrm{lb} \mathrm{N}}{1000 \mathrm{ft}^{2}}=$ depth of irrigation water $($ inches $) \times \mathrm{N}$ concentration $(\mathrm{mg} / \mathrm{L}$ or $\mathrm{ppm}) \times 0.0052$
Eq. 1

The coefficient of 0.0052 is used to convert from units of inches and $\mathrm{mg} / \mathrm{L}$ or ppm to units of pounds per 1000 square feet. For example, if 30 inches of reclaimed water are used for irrigation over the course of a growing season and the reclaimed water contains an average concentration of $10 \mathrm{mg} / \mathrm{L}$ of $\mathrm{N}$, then using Equation 1: $30 \times 10 \times 0.0052$ $=1.6 \mathrm{lbs}$ of $\mathrm{N}$ is applied per 1000 square feet of irrigated landscape.

Fertilizer recommendations for phosphorus are usually reported in units of $\mathrm{P}_{2} \mathrm{O}_{5}$ (phosphate) while phosphorus concentrations of reclaimed water are usually reported in units of elemental $\mathrm{P}$. To determine how much $\mathrm{P}_{2} \mathrm{O}_{5}$ has been applied using reclaimed water, elemental $\mathrm{P}$ must be converted to $\mathrm{P}_{2} \mathrm{O}_{5}$. The concentration of $\mathrm{P}$ is multiplied by 2.29 to convert from $\mathrm{P}$ to $\mathrm{P}_{2} \mathrm{O}_{5}$. So, to calculate the amount of $\mathrm{P}_{2} \mathrm{O}_{5}$ supplied per 1000 square feet from the inches of reclaimed water used for irrigation and the concentration of P, use the equation below:

$\frac{\mathrm{lb}_{2} \mathrm{O}_{5}}{1000 \mathrm{ft}^{2}}=$ depth of irrigation water (inches $) \times \mathrm{P}$ concentration $(\mathrm{mg} / \mathrm{L}$ or ppm $) \times 0.0052 \times 2.29$ Eq. 2

Tables 1 and 2 were created using Equations 1 and 2 and can be used to determine the amount of $\mathrm{N}$ and $\mathrm{P}_{2} \mathrm{O}_{5}$ supplied in reclaimed water in pounds per 1000 square feet for various irrigation amounts and $\mathrm{N}$ and $\mathrm{P}$ concentrations. Although Tables 1 and 2 show the total amount of $\mathrm{N}$ and $\mathrm{P}_{2} \mathrm{O}_{5}$ supplied from reclaimed water, these amounts are not necessarily the amounts that the plant will use. Effective utilization will depend on both proper irrigation and the timing of the supply.

Tables 1 and 2 also show the amount of $\mathrm{N}$ and $\mathrm{P}_{2} \mathrm{O}_{5}$ supplied at some very high irrigation amounts (e.g., 50, 100, and 150 inches). It is important to note that these irrigation amounts are far more than would be needed by any landscape in Florida over the course of a year. The amounts of $\mathrm{N}$ and $\mathrm{P}_{2} \mathrm{O}_{5}$ supplied at these high irrigation amounts can be more properly viewed as an indication of the amounts that could be leached to groundwater rather than an amount that could potentially be utilized by plants, since at these 
Table 1. Nitrogen supplied by reclaimed water using inches of irrigation applied

\begin{tabular}{|c|c|c|c|c|c|c|c|c|}
\hline \multirow{3}{*}{$\begin{array}{l}\text { Nitrogen Concentration } \\
\text { in Reclaimed Water } \\
\text { (mg/L N or ppm N) }\end{array}$} & \multicolumn{8}{|c|}{ Nitrogen Applied (Ib N per 1000 square feet) } \\
\hline & \multicolumn{8}{|c|}{ Inches of Reclaimed Water Applied for Irrigation } \\
\hline & 1 & 5 & 10 & 20 & 30 & 50 & 100 & 150 \\
\hline 1.0 & $<0.1$ & $<0.1$ & 0.1 & 0.1 & 0.2 & 0.3 & 0.5 & 0.8 \\
\hline 2.0 & $<0.1$ & 0.1 & 0.1 & 0.2 & 0.3 & 0.5 & 1.0 & 1.6 \\
\hline 3.0 & $<0.1$ & 0.1 & 0.2 & 0.3 & 0.5 & 0.8 & 1.6 & 2.3 \\
\hline 5.0 & $<0.1$ & 0.2 & 0.3 & 0.5 & 0.8 & 1.3 & 2.6 & 3.9 \\
\hline 10.0 & 0.1 & 0.3 & 0.5 & 1.0 & 1.6 & 2.6 & 5.2 & 7.8 \\
\hline 20.0 & 0.1 & 0.5 & 1.0 & 2.1 & 3.1 & 5.2 & 10.4 & 15.6 \\
\hline 30.0 & 0.2 & 0.8 & 1.6 & 3.1 & 4.7 & 7.8 & 15.6 & 23.4 \\
\hline
\end{tabular}

Table 2. Phosphate supplied by reclaimed water using inches of irrigation applied

\begin{tabular}{|c|c|c|c|c|c|c|c|c|}
\hline \multirow{3}{*}{$\begin{array}{c}\text { Phosphorus Concentration in } \\
\text { Reclaimed Water (mg/L P or } \\
\text { ppm P) }\end{array}$} & \multicolumn{8}{|c|}{ Phosphate Applied (Ib $\mathrm{P}_{2} \mathrm{O}_{5}$ per 1000 square feet) } \\
\hline & \multicolumn{8}{|c|}{ Inches of Reclaimed Water Applied for Irrigation } \\
\hline & 1 & 5 & 10 & 20 & 30 & 50 & 100 & 150 \\
\hline 0.10 & $<0.1$ & $<0.1$ & $<0.1$ & $<0.1$ & $<0.1$ & 0.1 & 0.1 & 0.2 \\
\hline 0.25 & $<0.1$ & $<0.1$ & $<0.1$ & 0.1 & 0.1 & 0.1 & 0.3 & 0.4 \\
\hline 0.50 & $<0.1$ & $<0.1$ & 0.1 & 0.1 & 0.2 & 0.3 & 0.6 & 0.9 \\
\hline 0.75 & $<0.1$ & $<0.1$ & 0.1 & 0.2 & 0.3 & 0.4 & 0.9 & 1.3 \\
\hline 1.0 & $<0.1$ & 0.1 & 0.1 & 0.2 & 0.4 & 0.6 & 1.2 & 1.8 \\
\hline 2.0 & $<0.1$ & 0.1 & 0.2 & 0.5 & 0.7 & 1.2 & 2.4 & 3.6 \\
\hline 5.0 & 0.1 & 0.3 & 0.6 & 1.2 & 1.8 & 3.0 & 6.0 & 8.9 \\
\hline
\end{tabular}

high irrigation rates the plant nutrient uptake efficiency will be greatly reduced.

\section{Using the Number of Gallons from a Utility Bill}

The amount of $\mathrm{N}$ and $\mathrm{P}_{2} \mathrm{O}_{5}$ supplied in reclaimed water can also be determined from the gallons of reclaimed water reported on a utility bill. Not everyone who uses reclaimed water can determine this from their utility bill since many users are charged a flat monthly rate and the volume used is not metered. But if it is metered, the quantity of reclaimed water used is reported on a utility bill as the number of gallons used during the billing period. In order to use Tables 1 and 2, the number of gallons of reclaimed water used must be converted to the inches of water applied over the area irrigated as follows (Eq. 3):

inches of reclaimed water applied $=\frac{\text { gallons of reclaimed water used }}{\text { irrigated area }\left(\mathrm{ft}^{2}\right)} \times 1.60$ Eq. 3
Tables 3 and 4 can also be used to determine the amount of $\mathrm{N}$ and $\mathrm{P}_{2} \mathrm{O}_{5}$ (in units of lbs) supplied by reclaimed water based on the number of gallons used. To compare these numbers to UF/IFAS fertilization recommendations (which are given as $\mathrm{lb} \mathrm{N}$ or $\mathrm{P}_{2} \mathrm{O}_{5}$ per 1000 square feet), the lbs of $\mathrm{N}$ and $\mathrm{P}_{2} \mathrm{O}_{5}$ in Tables 3 and 4 must be divided by the irrigated area (in square feet) and then multiplied by 1000 (Eq. 4):

$\frac{\mathrm{lb} \mathrm{N} \text { or } \mathrm{P}_{2} \mathrm{O}_{5}}{1000 \mathrm{ft}^{2}}=\frac{\text { lb of } \mathrm{N} \text { or } \mathrm{P}_{2} \mathrm{O}_{5} \text { from Table } 4 \text { or Table } 5}{\text { irrigated area }\left(\mathrm{ft}^{2}\right)} \times 1000$ Eq. 4

Although Tables 3 and 4 show the total amount of $\mathrm{N}$ and $\mathrm{P}_{2} \mathrm{O}_{5}$ supplied from reclaimed water, these amounts are not necessarily the amounts that will be used by the plant. Effective utilization will depend on both proper irrigation and the timing of the supply. 
Table 3. Nitrogen supplied by reclaimed water using gallons of water applied

\begin{tabular}{|c|c|c|c|c|c|c|}
\hline \multirow{4}{*}{$\begin{array}{c}\text { Nitrogen } \\
\text { Concentration in } \\
\text { Reclaimed Water } \\
\text { (mg/L N or ppm N) }\end{array}$} & \multicolumn{6}{|c|}{ Nitrogen Applied (Ib N) ${ }^{a}$} \\
\hline & \multirow{2}{*}{\multicolumn{6}{|c|}{ Gallons of Reclaimed Water Applied for Irrigation }} \\
\hline & & & & & & \\
\hline & 1,000 & 5,000 & 10,000 & 50,000 & 100,000 & 500,000 \\
\hline 1.0 & $<0.1$ & $<0.1$ & 0.1 & 0.4 & 0.8 & 4.2 \\
\hline 2.0 & $<0.1$ & 0.1 & 0.2 & 0.8 & 1.7 & 8.3 \\
\hline 3.0 & $<0.1$ & 0.1 & 0.3 & 1.3 & 2.5 & 12.5 \\
\hline 5.0 & $<0.1$ & 0.2 & 0.4 & 2.1 & 4.2 & 20.9 \\
\hline 10.0 & 0.1 & 0.4 & 0.8 & 4.2 & 8.3 & 41.7 \\
\hline 20.0 & 0.2 & 0.8 & 1.7 & 8.3 & 16.7 & 83.5 \\
\hline 30.0 & 0.3 & 1.3 & 2.5 & 12.5 & 25.0 & 125.2 \\
\hline
\end{tabular}

Table 4. Phosphate supplied by reclaimed water using gallons of water applied

\begin{tabular}{|c|c|c|c|c|c|c|}
\hline \multirow{4}{*}{$\begin{array}{l}\text { Phosphorus Concentration } \\
\text { in Reclaimed Water } \\
\text { (mg/L P or ppm P) }\end{array}$} & \multicolumn{6}{|c|}{ Phosphate Applied $\left(\mathbf{I b} \mathbf{P}_{2} \mathbf{O}_{5}\right)^{a}$} \\
\hline & \multirow{2}{*}{\multicolumn{6}{|c|}{ Gallons of Reclaimed Water Applied for Irrigation }} \\
\hline & & & & & & \\
\hline & 1,000 & 5,000 & 10,000 & 50,000 & 100,000 & 500,000 \\
\hline 0.10 & $<0.1$ & $<0.1$ & $<0.1$ & 0.1 & 0.2 & 1.0 \\
\hline 0.25 & $<0.1$ & $<0.1$ & $<0.1$ & 0.2 & 0.5 & 2.4 \\
\hline 0.50 & $<0.1$ & $<0.1$ & 0.1 & 0.5 & 1.0 & 4.8 \\
\hline 0.75 & $<0.1$ & 0.1 & 0.1 & 0.7 & 1.4 & 7.2 \\
\hline 1.0 & $<0.1$ & 0.1 & 0.2 & 1.0 & 1.9 & 9.6 \\
\hline 2.0 & $<0.1$ & 0.2 & 0.4 & 1.9 & 3.8 & 19.1 \\
\hline 5.0 & 0.1 & 0.5 & 1.0 & 4.8 & 9.6 & 47.8 \\
\hline
\end{tabular}

\section{Should Fertilizer Be Applied When Irrigating with Reclaimed Water?}

Depending on the $\mathrm{N}$ and $\mathrm{P}$ concentrations in reclaimed water, the quantity of reclaimed water used for irrigation, and the timing of the $\mathrm{N}$ and $\mathrm{P}$ supplied, it may be possible that little or no additional fertilizer will be needed (if supplied in the right amount at the right time). Supplemental fertilizer applications will depend on the desired landscape (e.g., the fertilization rate followed). For example, if the "basic" (lowest) UF/IFAS recommended fertilization of $2 \mathrm{lbs}$ of $\mathrm{N}$ per 1000 square feet per year is followed for a St. Augustinegrass lawn in North Florida (Sartain 2007; http://edis.ifas.ufl.edu/lh014), an application of 30 inches of reclaimed water with a $\mathrm{N}$ concentration of $10 \mathrm{mg} / \mathrm{L}$ would add $1.6 \mathrm{lbs}$ of $\mathrm{N}$ per 1000 square feet (from Table 1). If all of the $\mathrm{N}$ applied is effectively utilized (applied at the right time and the lawn was not over-irrigated), only an additional 0.4 lbs N per 1000 square feet would theoretically be required to meet the UF/IFAS recommendation of $2 \mathrm{lbs}$ of $\mathrm{N}$ per 1000 square feet.
However, the amount of $\mathrm{N}$ and $\mathrm{P}$ supplied by reclaimed water is not necessarily the amount that will be used by plants. For example, $1.6 \mathrm{lbs}$ of $\mathrm{N}$ per 1000 square feet supplied in small amounts over an entire growing season will likely not produce the same results compared to the same $1.6 \mathrm{lbs}$ of $\mathrm{N}$ per 1000 square feet supplied at times that it can be best utilized by plants. Less than ideal utilization may require application of more than 0.4 lbs N per 1000 square feet of supplemental fertilizer to achieve the same results that would be expected from following the UF/IFAS recommended fertilization schedules. Fertilization plans should be adjusted based on the timing of the supply of $\mathrm{N}$ and $\mathrm{P}$ from reclaimed water.

The nutrient uptake efficiency of a plant is defined simply as the amount of a nutrient taken up by the plant divided by the amount applied. The nutrient uptake efficiency is an effective metric to quantify the added nutrients used by the plant and not lost to leaching or runoff. The factors that influence the nutrient uptake efficiency include the water uptake efficiency and the timing and amount of nutrient applications. The water uptake efficiency of a plant is 
simply the quantity of water taken up by the plant divided by the quantity of irrigation applied. The higher the water uptake efficiency, the better nutrients are held in the root zone where they can be taken up by plants. So, maximizing water uptake efficiency will also improve nutrient uptake efficiency. Excessive irrigation will reduce the water use efficiency and, in turn, the nutrient uptake efficiency. The timing of nutrient applications affects the nutrient uptake efficiency, depending on how well it matches plant uptake patterns. The more similar nutrient applications are to the uptake pattern of the plant, the higher the nutrient uptake efficiency will be. In addition, the nutrient uptake efficiency is usually lowest in highly/excessively fertilized plants. To take advantage of the $\mathrm{N}$ and $\mathrm{P}$ in reclaimed water more fully, it is recommended that high fertilizer rates not be followed. Effective utilization will depend on the timing of the supply and proper irrigation practices.

\section{How Important Is Proper Irrigation When Using Reclaimed Water?}

Proper irrigation - applying just what is needed and not over-irrigating - is just as important or even more important when using reclaimed water. Over-irrigation results in applying more water than the soil within the plant root zone can hold. This results in leaching of water, and the $\mathrm{N}$ and $\mathrm{P}$ within it, into deeper soil layers or into groundwater. Irrigation systems should be properly adjusted to prevent overspray onto impervious surfaces (roads, driveways, and sidewalks), since this will result in reclaimed water entering the stormwater system. Reclaimed water in the stormwater system will increase nutrient loads to retention ponds and receiving waters and increase plant and algal growth.

An efficient, properly maintained, and calibrated irrigation system should follow an irrigation schedule based on seasonal water needs with separate irrigation zones for different plant types. However, over-irrigation by homeowners appears to be quite common. Augustin (2000; http://ufdc. ufl.edu/UF00026380/) found that a properly irrigated lawn in Florida required between 19 inches of irrigation water per year in Tallahassee to 35 inches per year in Miami. In a recent study in central Florida, Haley et al. (2007) found that homeowners applied 2-3 times more irrigation water than what the plants need. Anecdotal evidence suggests that many users of reclaimed water may over-irrigate more often than those who use potable (drinking quality) water for irrigation. A possible reason for this is the typically lower cost of reclaimed water. In addition, many users of reclaimed water are charged only a flat monthly fee, no matter how much they actually use, and may have a greater tendency to "set and forget" their irrigation system.

As mentioned in the previous section, nutrient uptake efficiency is directly linked to water uptake efficiency. Over-irrigation will reduce the water uptake efficiency, which will then reduce the nutrient uptake efficiency since the nutrients simply do not remain in the root zone long enough to be taken up by plants. In over-irrigation situations, Tables 1-4 may more accurately reflect the amount of nutrients leached to groundwater rather than what plants may potentially utilize.

For more information on these topics, see the following publications:

- Home Landscape Irrigation Efficiency - see Haley et al. (2008; http://edis.ifas.ufl.edu/fy1043)

- Calibrating Irrigation Systems - see Trenholm et al. (2001; http://edis.ifas.ufl.edu/lh026)

- Irrigation System Run Times - see the Urban Irrigation Scheduler (http://fawn.ifas.ufl.edu/tools/urban_irrigation/) and the related document on the operation of residential irrigation controllers by Dukes and Haman (2002; http://edis.ifas.ufl.edu/ae220)

- Home Irrigation and Landscape Combinations for Water Conservation - see Haley et al. (2005; http://edis.ifas.ufl. edu/ae287)

\section{Using the Information in This Publication to Estimate a Fertilizer Offset}

As previously mentioned, the amount of $\mathrm{N}$ and $\mathrm{P}$ supplied by reclaimed water shown in Tables 1-4 is not necessarily the amount that plants will use. The amount plants use depends on the nutrient uptake efficiency (NUE). In turn, the NUE depends on the water uptake efficiency and the timing and amount of nutrient applications. Thus, when using reclaimed water the NUE can vary greatly from a relatively high value (e.g., a case where the reclaimed water is applied only during the active growing season with amounts of $\mathrm{N}$ and $\mathrm{P}$ less than the fertilizer recommendations) to a relatively low value (e.g., a case where the reclaimed water is applied year-round, including during the dormant season and times the plant is less able to effectively use the applied nutrients, with amounts of $\mathrm{N}$ and $\mathrm{P}$ at or above recommendations). For example, if only $50 \%$ of the reclaimed 
water was applied during the active growing season, and the plant was only able to take up $50 \%$ of the nutrients during that time (due to the other components of NUE, the water uptake efficiency, and the amount applied), then the NUE would be $0.5 \times 0.5=0.25$. Therefore, the plant would effectively use only $25 \%$ of the amount applied as listed in Tables 1-4. Applying this to the previous example where 1.6 lbs of $\mathrm{N}$ per 1000 square feet was applied, the plant would actually use only $0.4 \mathrm{lbs}(1.6 \times 0.25=0.4)$.

\section{What Are the Concerns When Irrigating with Reclaimed Water?}

Several significant issues with using reclaimed water for landscape irrigation include (1) the timing of the supply of nutrients, (2) the relative amounts of $\mathrm{N}$ to $\mathrm{P}$ in the reclaimed water compared to the relative amounts beneficial to plants, and (3) the potential to over-apply a nutrient ( $\mathrm{P}$ in particular) in the process of meeting the irrigation needs of the landscape.

Depending on the timing of the $\mathrm{N}$ and $\mathrm{P}$ supplied by reclaimed water, the amount of $\mathrm{N}$ and $\mathrm{P}$ in reclaimed water may not be enough to support optimum growth during the height of the growing season. Hence, supplemental fertilization may be desired. In addition, the plant may not need or use the $\mathrm{N}$ and $\mathrm{P}$ supplied toward the end of the growing season or during the winter dormant season. Care must be taken when using reclaimed water to achieve the desired results and to avoid applying excess $\mathrm{N}$ and $\mathrm{P}$ at certain times of the year. Information on UF/IFAS recommended fertilization rates and the timing of $\mathrm{N}$ and $\mathrm{P}$ applications for turfgrasses in Florida can be found in Sartain (2007; http://edis.ifas.ufl.edu/lh014), while similar information for landscape plants can be found in Knox et al. (2002; http:// edis.ifas.ufl.edu/ep114).

The relative amounts of $\mathrm{N}$ to $\mathrm{P}$ of reclaimed water are rarely the same as those needed by plants. For example, if the plant requirement for one nutrient is met, the requirement of the other is likely not met or is exceeded. If the requirement for one nutrient is not yet met, supplemental fertilizer can be applied, if desired. Care should be taken to never exceed the plant requirement of either $\mathrm{N}$ or $\mathrm{P}_{2} \mathrm{O}_{5}$ when irrigating with reclaimed water, since this could result in runoff or leaching of excess $\mathrm{N}$ and $\mathrm{P}$.

Finally, care should be taken when irrigating with reclaimed water in locations where the soils contain ample P or where $\mathrm{P}$ pollution of surface water or groundwater is a problem. As of December 31, 2007, the application of $\mathrm{P}_{2} \mathrm{O}_{5}$ in fertilizers to urban turf is limited to $0.5 \mathrm{lbs}_{2} \mathrm{O}_{5}$ per
1000 square feet per year according to the statewide Urban Turf Fertilizer Rule (Dubberly 2007; http://flaes.org/pdf/ Urban_turf_fact_sheet.pdf). Applications greater than 0.5 lbs $\mathrm{P}_{2} \mathrm{O}_{5}$ per 1000 square feet per year must be justified by soil testing to show that additional $\mathrm{P}_{2} \mathrm{O}_{5}$ is needed. The rule currently applies only to bagged fertilizer, not to reclaimed water. However, as can be seen in Table 2, applying more than approximately 20 inches of reclaimed water that has $2.0 \mathrm{mg} / \mathrm{L}$ of $\mathrm{P}$ would exceed the limit set by the Urban Turf Fertilizer Rule. If the reclaimed water has $5.0 \mathrm{mg} / \mathrm{L}$ of $\mathrm{P}$, then even 10 inches of irrigation with reclaimed water would exceed this limit. This illustrates the importance of knowing the supply of nutrients received in reclaimed water and incorporating this information into landscape fertilization and irrigation planning.

\section{What Are the Potential Cost Savings of Irrigating with Reclaimed Water?}

Since reclaimed water supplies at least some of the $\mathrm{N}$ and $\mathrm{P}$ that would otherwise be applied in fertilizer, it is likely that less $\mathrm{N}$ and $\mathrm{P}$ fertilizer will be needed. Less fertilizer used translates directly to a financial savings. The value of the nutrients supplied by reclaimed water and the potential savings in fertilizer costs can be determined by first determining the cost per pound of $\mathrm{N}$ or $\mathrm{P}_{2} \mathrm{O}_{5}$. This can be estimated using the following equation:

$\frac{\text { Price per } \mathrm{lb} \text { of fertilizer } \times 100}{\text { Percent of } \mathrm{N} \text { or } \mathrm{P}_{2} \mathrm{O}_{5} \text { of the fertilizer }}=$ Price per $\mathrm{lb}$ of $\mathrm{N}$ or $\mathrm{P}_{2} \mathrm{O}_{5}$ Eq. 5

For example, if a $25-\mathrm{lb}$ bag of fertilizer costs $\$ 14.95$, then the price per pound of fertilizer is $\$ 14.95$ divided by $25 \mathrm{lbs}$ $=\$ 0.60$. If the fertilizer contains $14 \% \mathrm{~N}$, then the price per pound of $\mathrm{N}$ can be calculated from equation 5: $\$ 0.60 \times 100$ $\div 14 \%=\$ 4.29$ per pound of $\mathrm{N}$.

To calculate the value of the $\mathrm{N}$ or $\mathrm{P}_{2} \mathrm{O}_{5}$ supplied in reclaimed water for the entire landscape, use the following equation:

Price per lb of $\mathrm{N}$ or $\mathrm{P}_{2} \mathrm{O}_{5} \times \frac{1 \mathrm{~b} \mathrm{~N} \text { or } \mathrm{P}_{2} \mathrm{O}_{5} \text { applied }}{1000 \text { square feet }} \times$ square feet of landscape
$=$ Value of the $\mathrm{N}$ or $\mathrm{P}_{2} \mathrm{O}_{5}$ supplied Eq. 6

So if 1.6 pounds of $\mathrm{N}$ were supplied in reclaimed water per 1000 square feet and the landscape was 5000 square 
feet in size, then using equation 6: $\$ 4.29$ per pound of $\mathrm{N}$ $\times 1.6$ pounds $\mathrm{N}$ per 1000 square feet $\times 5000$ square feet $=$ $\$ 34.32$. This means $\$ 34.32$ is the value of the $\mathrm{N}$ supplied in reclaimed water. Similar calculations can be made for $\mathrm{P}_{2} \mathrm{O}_{5}$. This calculation assumes that all of the $\mathrm{N}$ in reclaimed water is taken up by the plant, which may not be the case as previously discussed.

Similarly, if Tables 3 and 4 are used to determine the amount of $\mathrm{N}$ and $\mathrm{P}$ supplied by reclaimed water based on the number of gallons used as reported in a utility bill, then the value of the nutrients supplied can be determined from the following equation:

Price per lb of $\mathrm{N}$ or $\mathrm{P}_{2} \mathrm{O}_{5} \times$ Amount of $\mathrm{N}$ or $\mathrm{P}_{2} \mathrm{O}_{5}$ applied (lb) $=$ Value of the $\mathrm{N}$ or $\mathrm{P}_{2} \mathrm{O}_{5}$ supplied

Eq. 7

These calculations of cost savings only apply to the amount of nutrients utilized by the plants. As previously mentioned, the amount of nutrients supplied in reclaimed water is not necessarily the amount plants will use. These calculations only take into account the potential cost savings in fertilizer that would no longer need to be applied. Additional savings can also be achieved when irrigating with reclaimed water since reclaimed water typically costs less per gallon than drinking water. This difference in cost will differ from utility to utility. The expected total cost savings will depend both on the amount of fertilizer that no longer needs to be applied and the reduced cost of reclaimed water compared to using potable (drinking quality) water for irrigation.

\section{Final Remarks}

While reclaimed water contains $\mathrm{N}$ and $\mathrm{P}$ that can potentially be used by plants, these nutrients can be effectively utilized only when delivered in the right manner and at the right time. The calculations in this document (including Tables 1-4) indicate the amount of $\mathrm{N}$ and $\mathrm{P}$ applied to the land when irrigating with reclaimed water, not the amount that plants will use. Effectively utilizing the $\mathrm{N}$ and $\mathrm{P}$ in reclaimed water and avoiding unintended environmental impacts will depend on the following:

- Knowing the amount and timing of the supply of $\mathrm{N}$ and $\mathrm{P}$ in reclaimed water

- Knowing the $\mathrm{N}$ and $\mathrm{P}$ uptake pattern of the plants irrigated with reclaimed water
- Practicing proper irrigation to avoid over-irrigation, maximize nutrient uptake efficiency, and avoid overspray onto driveways, sidewalks, and roads

Currently, there is not enough information to make specific recommendations on the amount of $\mathrm{N}$ and $\mathrm{P}$ in reclaimed water that plants will use or the amount that fertilizer applications can be reduced when irrigating with reclaimed water. The amount of $\mathrm{N}$ and $\mathrm{P}$ in reclaimed water that plants use will vary on a case-by-case basis and will depend on the amount supplied, the timing of supply, and the efficiency of the irrigation system. In general, for those who wish to maximize the nutrient uptake efficiency, it is best to begin on the low end of fertilizer applications to the landscape when irrigating with reclaimed water. A topic of current research is to find detailed recommendations on the amount of $\mathrm{N}$ and $\mathrm{P}$ that plants will use from reclaimed water and the amount that fertilizer applications can be reduced when irrigating with reclaimed water.

\section{References}

Augustin, B.J. 2000. Water Requirements of Florida Turfgrasses. Bulletin 200. Gainesville: University of Florida Institute of Food and Agricultural Sciences. http://ufdc.ufl. edu/UF00026380/.

Dubberly, D. 2007. Urban Turf Fertilizer Rule. Florida Department of Agriculture and Consumer Services Fact Sheet. Tallahassee: Florida Department of Agriculture and Consumer Services. http://flaes.org/pdf/Urban_turf_fact_ sheet.pdf.

Dukes, M.D., and D.Z. Haman. 2002. Operation of Residential Irrigation Controllers. AE220. Gainesville: University of Florida Institute of Food and Agricultural Sciences. http:// edis.ifas.ufl.edu/ae220.

Duncan, R.R., R.N. Carrow, and M.T. Huck. 2009. Turfgrass and Landscape Irrigation Water Quality: Assessment and Management. Boca Raton, FL: CRC Press.

Haley, M.B., M.D. Dukes, G.L. Miller, and D.Z. Haman. 2005. Home Irrigation and Landscape Combinations for Water Conservation in Florida. AE287. Gainesville: University of Florida Institute of Food and Agricultural Sciences. http://edis.ifas.ufl.edu/ae287.

Haley, M.B., M.D. Dukes, and G.L. Miller. 2007. "Residential Irrigation Water Use in Central Florida." Journal of Irrigation and Drainage Engineering 133(5):427-34. 
Haley, M.B., M.D. Dukes, S. Davis, M. Shedd, and B. Cadenas-Lailhacar. 2008. Energy Efficient Homes: The Irrigation System. FY1043. Gainesville: University of Florida Institute of Food and Agricultural Sciences. http://edis.ifas. ufl.edu/fy1043.

Knox, G., T. Broschat, J. Kidder, E. Gilman, L. Trenholm, R. Black, T. Wichman, D. Palmer, R. Zerba, C. White, A. Hunsberger, G. Israel, J. Cisar, K. Ruppert, D. Culbert, C. Kelly-Begazo, S.P. Brown, E. Buss, E. Worden, and C. Vavrina. 2002. Fertilizer Recommendations for Landscape Plants. ENH858. Gainesville: University of Florida Institute of Food and Agricultural Sciences. http://edis.ifas.ufl.edu/ ep114.

Martinez, C.J., and M.W. Clark. 2009. Using Reclaimed Water for Landscape Irrigation. AE449. Gainesville: University of Florida Institute of Food and Agricultural Sciences. http://edis.ifas.ufl.edu/ae449.

Parsons, L.R. 2009. Reclaimed Water for Homeowner Irrigation. HS1157. Gainesville: University of Florida Institute of Food and Agricultural Sciences. http://edis.ifas.ufl.edu/ hs1157.

Sartain, J.B. 2007. General Recommendations for Fertilization of Turfgrasses on Florida Soils. SL21. Gainesville: University of Florida Institute of Food and Agricultural Sciences. http://edis.ifas.ufl.edu/lh014.

Trenholm, L.E., J.B. Unruh, and J.L. Cisar. 2001. How to Calibrate your Sprinkler System. LH026. Gainesville: University of Florida Institute of Food and Agricultural Sciences. http://edis.ifas.ufl.edu/lh026. 